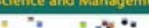

$\because \because$ International Journal of Service Science and Management

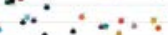

\title{
Instrumenting Community Health Agents to Address Child and Youth Violence at Home
}

\author{
Santos, M.V1; Batista, M.A.L2; Silva, V.C3; Oliveira, R.V4
}

1,2,3Estudantes do Curso de Bacharelado em Enfermagem. - IFPE; 4Docente/pesquisador do Departamento de Extensão (PIBEX)-IFPE

\begin{abstract}
Introduction: This is an experience report of a descriptive nature related to the project of university extension, developed by two professors and four undergraduate students in Nursing at the Federal Institute of Education, Science and Technology / IFPE, Campus Pesqueira. This research is linked to the extension project entitled "Child and adolescent as victims of domestic violence: sensitization workshops with Community Health Agents (ACS) of the municipality of pesqueira - PE to recognize and cope with child and juvenile violence." Objectives: The objective of this study was to use the ACS through awareness-raising workshops to recognize cases of domestic violence against children and to adopt means to confront this event. Methodology: The methodology was adopted focusing on the interests and knowledge of the participants, aiming at empowering the individuals' autonomy and emancipation. The study was carried out between February and October 2017 and had a weekly workload of twenty hours. For the development of the activities, the Family Health Strategies of the Municipality of Pesqueira-PE were selected, justifying the choice of the fact that these units present socio-economic vulnerability; as well as because it has already been a scenario of research on domestic accidents with children, thus characterizing itself as a context of teaching, research and extension experiences. Results and discussion: The sample consisted of $31 \mathrm{ACS}$, and guiding questions were elaborated to to construct a plan of intervention in the face of a case of violence, guaranteeing the continuity of care in the primary care network.

Conclusion: The research becomes relevant as the ACS are aware of the occurrences of child and juvenile violence and the subjects involved can reflect on the importance of adopting preventive behavior to minimize these cases.
\end{abstract}

*Correspondence to Author:

Santos, M.V

Estudantes do Curso de Bacharela-

do em Enfermagem. - IFPE

How to cite this article:

Santos, M.V; Batista, M.A.L; Silva, V.C; Oliveira, R.V. Instrumenting Community Health Agents to Address Child And Youth Violence at Home.International Journal of Service Science and Management, 2018, 1:3

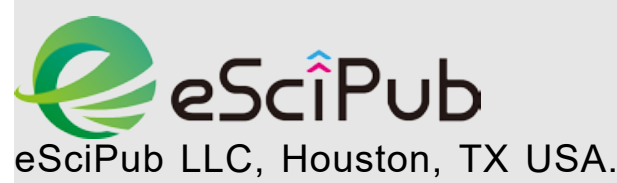

Website: http://escipub.com/

Keywords: Health Education; Child maltreatment; Family Health; Domestic violence 